\title{
Membrane Fouling Characteristics of a Side-Stream Tubular Anaerobic Membrane Bioreactor (AnMBR) Treating Domestic Wastewater
}

\author{
Nsanzumukiza Martin Vincent ${ }^{1,2,3}$ (D), Juan Tong ${ }^{1,2,3}$, Dawei Yu ${ }^{1,2,3}$, Junya Zhang ${ }^{1,2,3}$ and \\ Yuansong Wei $1,2,3,4, *$ (iD) \\ 1 State Key Joint Laboratory of Environmental Simulation and Pollution Control, Research Center for \\ Eco-Environmental Sciences, Chinese Academy of Sciences, Beijing 100085, China; \\ nsanzumumartiv_st@rcees.ac.cn (N.M.V.); hittj@163.com (J.T.); dwyu@rcees.ac.cn (D.Y.); \\ zjyzjjzmt@163.com (J.Z.) \\ 2 Department of Water Pollution Control Technology, Research Center for Eco-Environmental Sciences, \\ Chinese Academy of Sciences, Beijing 100085, China \\ 3 University of Chinese Academy of Sciences, Beijing 100049, China \\ 4 Institute of Energy, Jiangxi Academy of Sciences, Nanchang 330096, China \\ * Correspondence: yswei@rcees.ac.cn; Tel.: +86-10-6284-9690
}

Received: 25 March 2018; Accepted: 28 April 2018; Published: 5 May 2018

\begin{abstract}
A lab-scale of a side stream anaerobic membrane bioreactor (AnMBR) equipped with a tubular membrane operated at the mesophilic temperature of $37.0 \pm 1.2{ }^{\circ} \mathrm{C}$ for treating domestic wastewater was tested to investigate its performance and fouling characteristics at two organic loading rates (OLR) of $0.25 \mathrm{~kg} \mathrm{COD} \mathrm{m}^{-3} \mathrm{~d}^{-1}$, and $0.70 \mathrm{~kg} \mathrm{COD} \mathrm{m}^{-3} \mathrm{~d}^{-1}$, respectively. The AnMBR was operated for 600 days at sludge retention time (SRT) of 100 days. This AnMBR exhibits excellent chemical oxygen demand (COD) removal of $91 \%$ at $0.25 \mathrm{~kg} \mathrm{COD} \mathrm{m}^{-3} \mathrm{~d}^{-1}$, and $94 \%$ at $0.7 \mathrm{~kg} \mathrm{COD} \mathrm{m}^{-3} \mathrm{~d}^{-1}$ respectively, with effluent-soluble COD below $50 \mathrm{mg} / \mathrm{L}$. Chemically-enhanced cleaning method using $\mathrm{NaOH}, \mathrm{NaOCl}$, and citric acid solution were introduced for fouling investigation at these two stages. The results showed that sequential chemical cleaning of alkaline and acid were most effective to recover the membrane flux. The alkaline cleaning was effective at removing organic foulants, while citric acid cleaning was effective at removing the scalants. The analyses of the excitation emission matrix, gel permeation chromatography, and extracellular polymeric substances indicated that major components of membrane foulants were proteins, carbohydrates, humic, and fulvic acids. At $0.25 \mathrm{~kg} \mathrm{COD} \mathrm{m}^{-3} \mathrm{~d}^{-1}$, organic fouling was more prone to be trapped in the cake layers and responsible for membrane pore blockage, inorganic fouling exhibited marginal contribution to the membrane fouling behavior. However, at $0.70 \mathrm{~kg} \mathrm{COD} \mathrm{m}^{-3} \mathrm{~d}^{-1}$, high concentrations of organic and inorganic foulants supported an essential role of organic and inorganic fouling on membrane fouling behavior.
\end{abstract}

Keywords: tubular membrane; membrane fouling; organic matter; synthetic wastewater; excitation-emission matrix (EEM); inorganic element

\section{Introduction}

Wastewater treatment is essential to prevent pollution of aquatic environments [1]. Over the past years, global population growth and development [2] have led to intense water demand and wastewater discharge in the environment [3]. This is quite susceptible of environmental pollution, especially the organic matter loading in environment, thus, a reliable wastewater treatment and disposal system should be implemented [4]. Reliable and affordable wastewater treatment technology 
is a challenge in many parts of the world for domestic wastewater treatment. The application of anaerobic conventional technologies, such as up-flow anaerobic sludge blanket (UASB), expanded granular sludge blanket (EGSB), and strengthened circulation anaerobic (SCA) for low-strength domestic wastewater, have shown poor quality of effluent as a result of biomass loss [5,6]. The anaerobic digestion normally operates at mesophilic temperatures due to low biomass growth rate and the reduction of substrate utilization at low operational temperatures $[7,8]$. Conventional anaerobic technology has been the driving tool to deal with wastewater produced in different parts of the world $[9,10]$. However, this conventional anaerobic technology has been limited to meet society's needs.

The anaerobic membrane bioreactor (AnMBR) technology appeared to be the suitable emerging technology. AnMBR has gained in popularity for the treatment of both low- and high-strength wastewater [11] as membrane costs have dropped drastically [12]. This is largely because AnMBR has the ability to provide superior effluent quality for reuse [13], has a small footprint of operation [14], and nutrient recovery compared to conventional anaerobic treatment facility that relies on gravity sedimentation. The AnMBR process proved to be a reliable technology in tourist areas and public places for wastewater treatment. However, membrane fouling continues to be a primary challenge to the spread of the AnMBR system [15], because of its direct effect on capital and operating costs [16]. Membrane fouling and its control has been reported by researchers [17,18], and the parameters related to membrane and sludge properties affect membrane fouling. These parameters can be generally classified into four categories, including feed characteristics, sludge characteristics, membrane characteristics, and operational conditions. Membrane fouling, which is caused by the deposition of dissolved organic matter [19] and inorganic scalants [20] on the membrane surface, is regarded as one of the major setbacks for the application of AnMBR towards domestic wastewater treatment. To alleviate membrane fouling, significant efforts have been focused on the elaboration of a cleaning strategy combining both physical and chemical cleaning strategies $[18,19,21]$. Membrane permeate flushing was used in the cleaning process [22,23] but showed low efficiency for flux recovery [24], thus, chemical cleaning was addressed as an essential cleaning approach to control this fouling issue. Sodium hypochlorite $(\mathrm{NaOCl})$ is a commonly used cleaning reagent in in situ and ex situ cleaning due to its chemical stability and good cleaning efficiency $[14,25]$. Mei et al. found it effective at removing organic matter by $\mathrm{NaOH}$ cleaning on anaerobic ceramic membranes [26]. Zondervan et al. have reported on the cleaning effect of acidic, alkali, oxidizing, and sequestering agents in terms of cleaning rate and cleaning effectiveness, and acid cleaning was found to be the least effective [27].

The main objectives of this study were to investigate the performance, and elucidate membrane fouling characteristics, such as organic fouling and scaling, in order to develop membrane cleaning strategy of the AnMBR at two organic loading rates (OLR). An AnMBR equipped with tubular membrane is, thus, developed in this research for domestic wastewater treatment in tourist areas, schools, hotels, and public places, for the bright future connecting wastewater treatment and environmental sustainability for the benefit of both. It is expected that the treatment process will offer a solution to the shortcomings of water reuse programs to overcome seasonal water shortages in public places, tourist areas, and pollution issues associated with tourism activities in tropical areas.

\section{Materials and Methods}

\subsection{Lab-Scale Tubular AnMBR}

A $29 \mathrm{~L}$, completely-mixed anaerobic bioreactor was operated to treat simulated domestic wastewater, as shown in Figure 1. Solid-liquid separation was achieved using a tubular microfiltration, polyvinylidene fluoride (PVDF) membrane with a molecular weight cut-off of 20,000 Dalton (Beijing Tri-High Membrane Technology Co., Ltd., city, Beijing, China) with a total surface area of $0.011 \mathrm{~m}^{2}$. The mixed liquor in the bioreactor of AnMBR was pumped through the membrane module using a pump controlled by a programmable logic controller (PLC) system (PLC, SIMATIC S7-200CPU224XP, Siemens AG, Munich, Germany). 

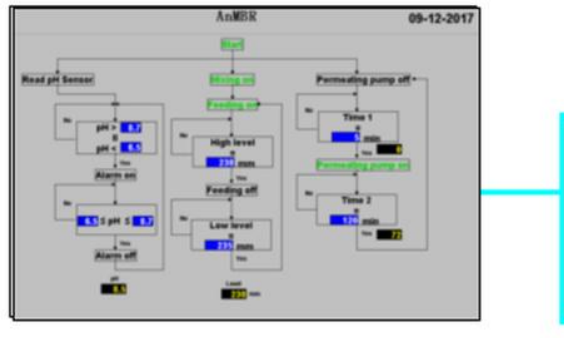

Linetypes

\author{
Pipeline \\ Biogas Data \\ $\mathrm{pH}$ Data \\ ORP Data
}

Control Signal

\title{
Pipelines
}

Control System Equipment

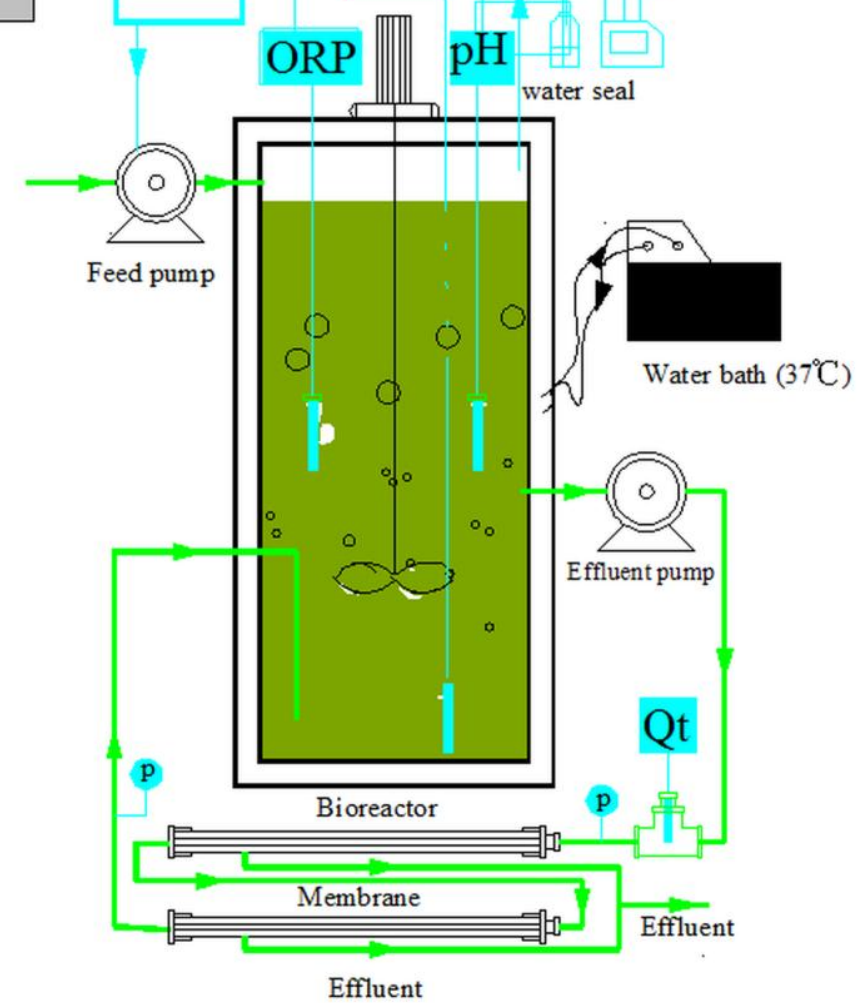

Figure 1. Schematic of the anaerobic membrane bioreactor (AnMBR). ORP: Oxidation reduction potential; Qt: Flow rate meter; p: Pressure gauge.

The trans-membrane pressure (TMP) was monitored using a gauge pressure valve (PGB-CC2-SBL, Ningbo Konoo Instrument Mfg. Co., Ltd., Ningbo, China) at the inlet and outlet of the membrane. The closed-loop recycle experiments were performed in such a way that the concentrate and permeate were continuously recycled to the bioreactor and reservoir, respectively. Reactor operation and data acquisition were monitored and controlled by the PLC system. The reactor temperature was kept in the mesophillic range with a water jacket system connected to the reactor. The bioreactor was equipped with a level sensor, pH sensor (E201-C, Leici Instrument Incorporated, Shanghai, China), and oxidation reduction potential (ORP) probe (HBM-100A, DKK-TOA Corporation, Tokyo, Japan), and the PLC program was responsible for the operation of all pumps, mixing, and sensors. The bioreactor port located on the front was connected to a biogas flow meter ( $\mu$ Flow, Bioprocess Control AB, Stockholm, Sweden).

\subsection{Operation of the Tubular AnMBR}

During the operational period, the AnMBR was fed with synthetic wastewater. The simulated domestic wastewater was prepared on the basis of glucose and sodium acetate as carbon sources, ammonium chloride was used as the ammonia source, the nutrient was augmented with phosphate, a nitrogen source, proteins, and the trace elements for correction of the growth of bacteria, and sodium hydrogen carbonate $\left(\mathrm{NaHCO}_{3}\right)$ was used to adjust the influent $\mathrm{pH}$. The AnMBR reactor was maintained 
at a mesophillic temperature of $37.0 \pm 1.2{ }^{\circ} \mathrm{C}$ throughout the study. The initial OLR during the first phase of operation was $0.25 \mathrm{~kg} \mathrm{COD} \mathrm{m}^{-3} \mathrm{~d}^{-1}$ (OLR), which corresponded to a hydraulic retention time (HRT) of $37.5 \mathrm{~h}$ and the second phase with an OLR of $0.70 \mathrm{~kg} \mathrm{COD} \mathrm{m}^{-3} \mathrm{~d}^{-1}$, which corresponded to an HRT of $13 \mathrm{~h}$. The sludge retention time (SRT) was 100 days in both phases. This AnMBR was operated at the filtration and relaxation modes of $60 \mathrm{~min}$ and $5 \mathrm{~min}$, respectively. For consistency, samples were collected at approximately the same time on each collection day under the constant trans-membrane flux. Samples were taken from the concentrate from tubular membrane and, mixed liquor in the reactors. The initial membrane flux was $165 \mathrm{~L} / \mathrm{m}^{2} \mathrm{~h}$, and this initial flux was measured with pure water before the treatment process.

\subsection{Membrane Cleaning Strategy}

In general, cleaning was applied at a low pressure to avoid forcing the fouling particles into membrane pores and forcing the fouling layer to adhere to the membrane surface, and the working pressure was monitored below $10 \mathrm{kpa}$ compared to the filtration process pressure of above $10 \mathrm{kpa}$. The flushing of the permeate was employed to prevent membrane fouling, and the pipe of the retentate outlet and inlet of the AnMBR bioreactor were then closed. Cleaning was carried out with the permeate side open and both permeate and retentate were recycled to the cleaning tank. The permeate cleaning was applied once every two days in a period of $30 \mathrm{~min}$. To characterize and evaluate the membrane fouling, the initial pure water flux of the virgin membrane was measured at $165 \mathrm{~L} / \mathrm{m}^{2} \mathrm{~h}$.

In this study, a subsequent chemical-enhanced cleaning method of $\mathrm{NaOH}, \mathrm{NaOCl}$, and citric acid solution were introduced, as shown in Figure S1a. The single cleaning process with these chemical reagents were also tested to elucidate the chemical cleaning effectiveness of single chemical reagents, as shown in Figure S1b. A $5 \mathrm{~L}$ vessel was used to prepare $4 \mathrm{~L}$ of cleaning solution with a concentration of $0.5 \mathrm{~mol} / \mathrm{L}$ of sodium hydroxide or citric acid and $5 \%$ (weight) of sodium hypochlorite for membrane cleaning, and the cleaning process was carried out over a period of $30 \mathrm{~min}$ in single or subsequent chemical cleanings, once every two months, or according to the fouling state manifestation. Before the membrane cleaning process, the pipe of the concentrate outlet and inlet of the AnMBR bioreactor were closed and cleaning was carried out with the permeate side open and both the permeate and cleaning solutions were recycled to the cleaning tank. After preparation of the chemical solution, a sequential cleaning of alkaline and acid solutions was used. At the beginning, tap water was used to clean the membrane over a period of $30 \mathrm{~min}$. After a period of $30 \mathrm{~min}$ of cleaning, membrane flux was measured, then the sequential chemical cleaning was applied. After each chemical application, tap water was used to measure the membrane flux and the next chemical was applied. For the single-chemical cleaning, each chemical solution was used to clean the membrane over a period of $30 \mathrm{~min}$ and after chemical cleaning, tap water was used to measure the membrane flux. Figure S1a,b shows the flux recovery and fouling ratio plotted as a function of chemical cleaning. Chemical cleaning was applied in order to decrease the membrane fouling and improve the AnMBR filtration performance. The cleaning scheme of the study is presented in Figure S1 and the membranes were considered cleaned when the water filtration flux was approximately in the range of the virgin membrane flux.

\subsection{Analysis Methods}

COD, $\mathrm{NH}_{4}{ }^{+}$, Mixed Liquor Suspended Solids (MLSS), and Mixed liquor volatile suspended solids (MLVSS) were determined using procedures outlined in the Standard Methods [28]. Samples were filtered through $0.45 \mu \mathrm{m}$ membrane before the soluble chemical oxygen demand (sCOD) concentrations were determined. Samples for extracellular polymeric substance (EPS) extraction were immediately stored at $-80^{\circ} \mathrm{C}$ prior to extraction. EPS was extracted by physical and chemical methods, centrifugation was used as the physical part of the extraction, followed by chemical extraction; formaldehyde and sodium hydroxide were the chemicals used [29]. Duplicate EPS extractions were performed for each sample. Proteins and carbohydrates in extracted EPS were quantified according to the Lowry assay and the Dubois method and determined by spectrophotometer at $488 \mathrm{~nm}$ and 
$750 \mathrm{~nm}$, respectively [29]. Fluorescence spectroscopy (F-7000, Hitachi, Tokyo, Japan) was used to investigate the major components of the organic matter in the feed, AnMBR, and treated water. The influent and AnMBR supernatant were diluted two times and the bound EPS, which represented high concentrations of organic matter, were diluted a hundred times and analyzed. Excitation emission matrix (EEM) spectra were obtained by measuring the excitation and emission spectra of water samples over a range of excitation wavelengths (Ex) between 200 and $400 \mathrm{~nm}$, emission wavelengths (Em) between 250 and $550 \mathrm{~nm}$, at $5 \mathrm{~nm}$ sampling intervals and a scan speed of $2400 \mathrm{~nm} / \mathrm{min}$ [30]. A gel permeation chromatography-UV detector (GPC) with a high-performance liquid chromatography (HPLC) system (Breeze 1525, Waters Co., Milford, CT, USA) was used to characterize the major components and the complexity of organic matter after the cleaning process [31], during the samples determinations, only samples with citric acid cleaning were diluted one hundred times and analyzed. FT-IR (Nicolet 8700, Thermo Electron Corporation, Boston, MA, USA) with a resolution of $4 \mathrm{~cm}^{-1}$ within 400-4000 $\mathrm{cm}^{-1}$ was used to characterize the functional groups of organic matter present in the fouling layer and the cleaned and fouled membrane. SEM-EDS (SEM-EDS, SU-8020, Hitachi, Tokyo, Japan) analysis of the AnMBR concentrate and membrane fouling layer were performed to elucidate the structure and composition of organic and inorganic foulants [32]. To analyze the fouled and cleaned membrane with scanning electron microscopy with energy dispersive X-ray spectroscopy (SEM-EDS) and fourier-transform infrared spectroscopy (FTIR), the fouled membrane was removed from the AnMBR setup and replaced with a new membrane. After breaking the tubular membrane, the inner part of the membrane was dissected carefully. The ex situ membrane cleaning was performed by soaking the dissected part of the membrane into alkaline and citric acid solution subsequently for $5 \mathrm{~h}$ each. For single cleaning, the dissected part of the membrane was soaked separately in chemical solution for $5 \mathrm{~h}$. The fouled and cleaned membranes were dried in an oven for $24 \mathrm{~h}$ at the temperature $35{ }^{\circ} \mathrm{C}$ to avoid the alteration of the membrane and foulants. The prepared samples were subjected to SEM-EDS and FTIR analysis. The particle size distributions of the AnMBR biomass were measured with a Malvern Mastersizer 2000 (Malvern Co., Worcestershire, UK).

\section{Results and Discussion}

\subsection{Performance of COD Removal}

The AnMBR was inoculated with anaerobic seed sludge of $20 \mathrm{~g} / \mathrm{L}$ of MLSS (mixed liquor suspended solids) and $11.69 \mathrm{~g} / \mathrm{L}$ of MLVSS (mixed liquor volatile suspended solids) from a brewery wastewater treatment plant. The AnMBR experienced an extended six-month start-up period due to the adaptation of the cleaning strategy. At this stage, soluble chemical oxygen demand (sCOD) concentration of the effluent fluctuated in the range of 70-250 mg/L, while the soluble COD in the influent was between 350 and $600 \mathrm{mg} / \mathrm{L}$. After the start-up period, the average COD removal rate was stable at $91 \%$ and the average soluble COD concentration in the effluent was less than $50 \mathrm{mg} / \mathrm{L}$, as shown in Figure 2. The performance of this study showed excellent COD removal compared to the previous studies. Ho et al. reported the COD removal efficiencies of $85 \%$ and $95 \%$ in two different experimental setups with the tubular membrane, respectively [33]. During this research, the HRT was $12 \mathrm{~h}$, while the temperature in bioreactor one was $15^{\circ} \mathrm{C}$ and $25^{\circ} \mathrm{C}$ in bioreactor two, compared to the current study of AnMBR with optimized HRT and fixed mesophilic temperature (Table 1) this emphasized the importance of both temperature and HRT optimization for good performance. Chu et al. reported the COD removal efficiency of $86 \%$ with a hollow fiber membrane [34], at a temperature of $25^{\circ} \mathrm{C}$ and HRT of $12 \mathrm{~h}$, while the AnMBR in this study operated at a mesophilic temperature and at two HRT of $37.5 \mathrm{~h}$ and $13 \mathrm{~h}$ (phase I and phase II), respectively. The high temperature is commonly suitable for the maximum specific growth and substrate utilization rates of microorganisms, and the temperature fluctuations are reported to affect the stability of bioreactor COD removal performance [18,35]. On the other hand, at psychrophilic conditions, anaerobic digestion presents a different setback, including a low biomass growth rate and a reduction of the microbial 
community substrate utilization $[7,8]$. Lin et al. reported the COD removal of $90.2 \%$, when HRT was $28 \mathrm{~h}$. However, when HRT was shortened to $10 \mathrm{~h}$, COD removal efficiency dropped slightly from $90.2 \%$ to $90 \%$ with treatment of municipal secondary wastewater [36]. Yue et al. reported the COD removal of $88.6 \pm 9.0 \%, 87.9 \pm 7.4 \%$, and $86.3 \pm 9.7 \%$, respectively, in three AnMBRs with ceramic membranes [37], which showed low organic matter removal efficiencies compared to the current AnMBR. Yue et al. carried out this research at mesophilic temperatures with HRT of 7.5 [37]. This poor COD removal efficiency is suggested to be related to the short HRT, the contact time between microorganisms and substrate was not sufficient, therefore, a part of the influent COD was allowed to leave the reactor without proper treatment. The AnMBR COD removal efficiency in mixed liquor in the first phase with an HRT of $37.5 \mathrm{~h}$ at $0.25 \mathrm{~kg} / \mathrm{m}^{3} \cdot \mathrm{d}$ was $82.51 \pm 5.42 \%$ while, in the second phase of the experiment with an HRT of $13 \mathrm{~h}$ at $0.7 \mathrm{~kg} / \mathrm{m}^{3} \cdot \mathrm{d}$, the mixed liquor COD removal efficiency was $87.33 \pm 3.48 \%$.

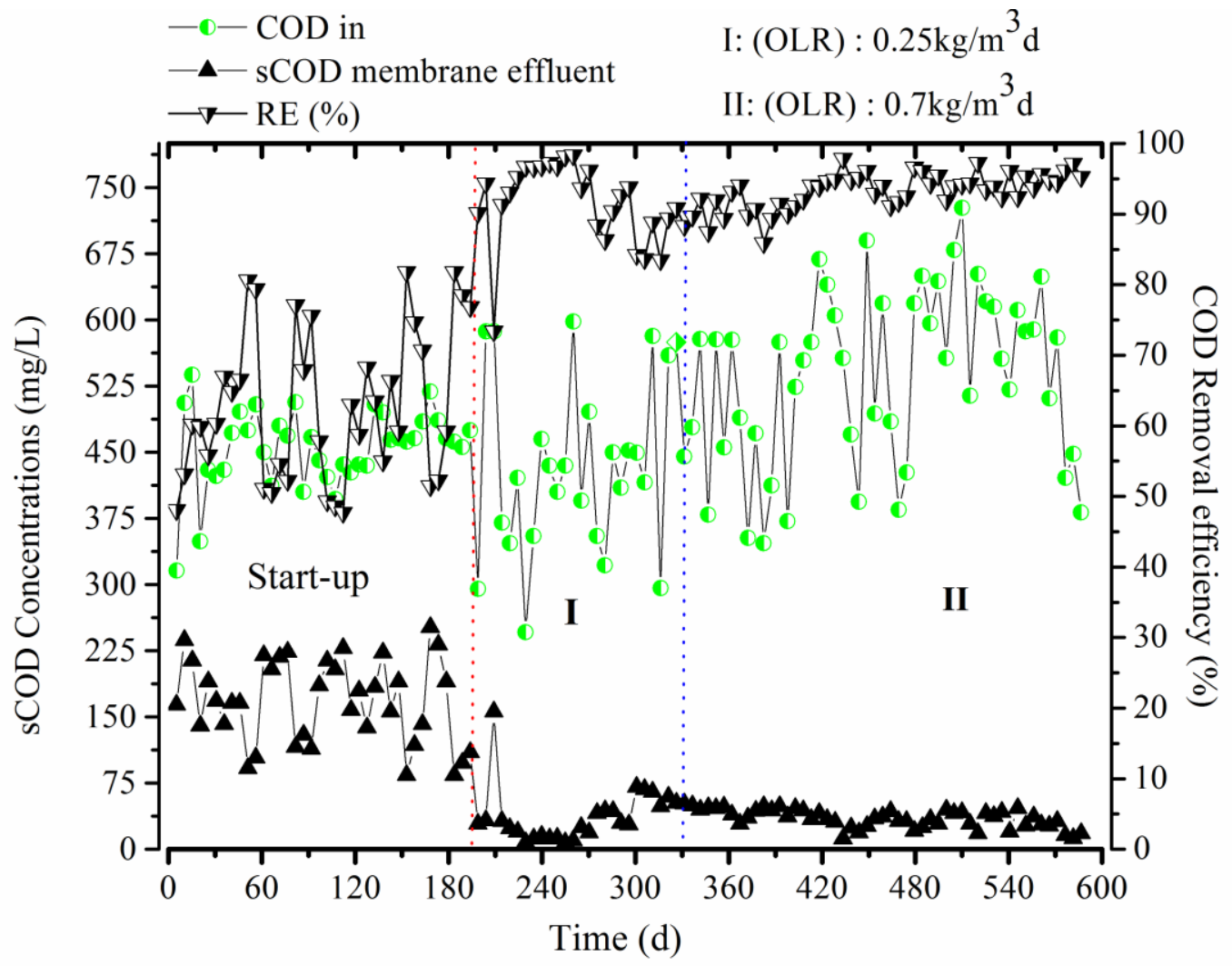

Figure 2. Soluble chemical oxygen demand (sCOD) fluctuation during the process.

This emphasized the ability of this microfiltration tubular membrane to retain the valuable amount of organic matter. However, previous research of Yue et al. reported a mixed liquor COD removal of $86 \pm 6.0 \%, 78.7 \pm 6.9 \%$, and $79.7 \pm 5.5 \%$ [37], which were lower than the results of this AnMBR (Table 1). During this study of AnMBR, the optimization of HRT proved to increase the organic matter removal (Table 1). As the HRT in this study was shortened from 37.5 to $13 \mathrm{~h}$, resulting in an OLR increase from 0.25 to $0.70 \mathrm{~kg} / \mathrm{COD} \mathrm{m} \mathrm{m}^{3} \mathrm{~d}$, the average COD removal efficiency was increased to $94 \%$ (Figure 2). The AnMBR MLSS concentrations were $7.51 \pm 1.41$ and $5.00 \pm 1.09$ in the first and second phases, respectively, and the MLSS value in Figure 3a showed a fluctuation trends of MLSS. The decrease of the MLSS was due to the cleaning strategy and SRT application during the operation, when the permeate cleaning strategy was stopped for two to three days, it illustrated that the MLSS increases, Figure 3a on days 360, 430, 460-480, and 515. The permeate cleaning strategy affected the COD removal performance during start-up and, after installing the suitable strategy for membrane cleaning (Section 2.2), the process operated steadily, with only a portion of the mixed 
liquor suspended solids being wasted in the pipe, which reflects the MLSS reduction during operation. The MLVSS/MLSS ratios in the first phase of the experiment was 0.7 while, in the second phase of the experiment, the ratio of MLVSS/MLSS decreased to about 0.6. The MLVSS/MLSS ratio drop was suggested to be associated with the accumulation of inorganic particles in the bioreactor.

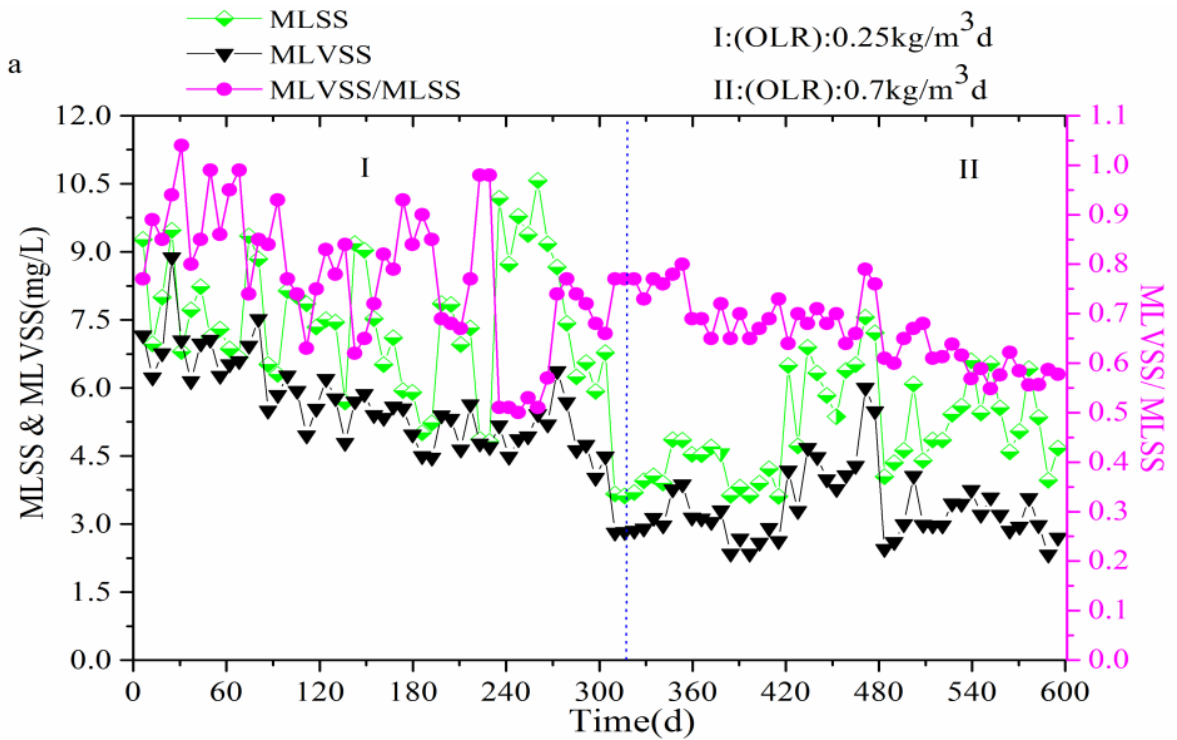

b

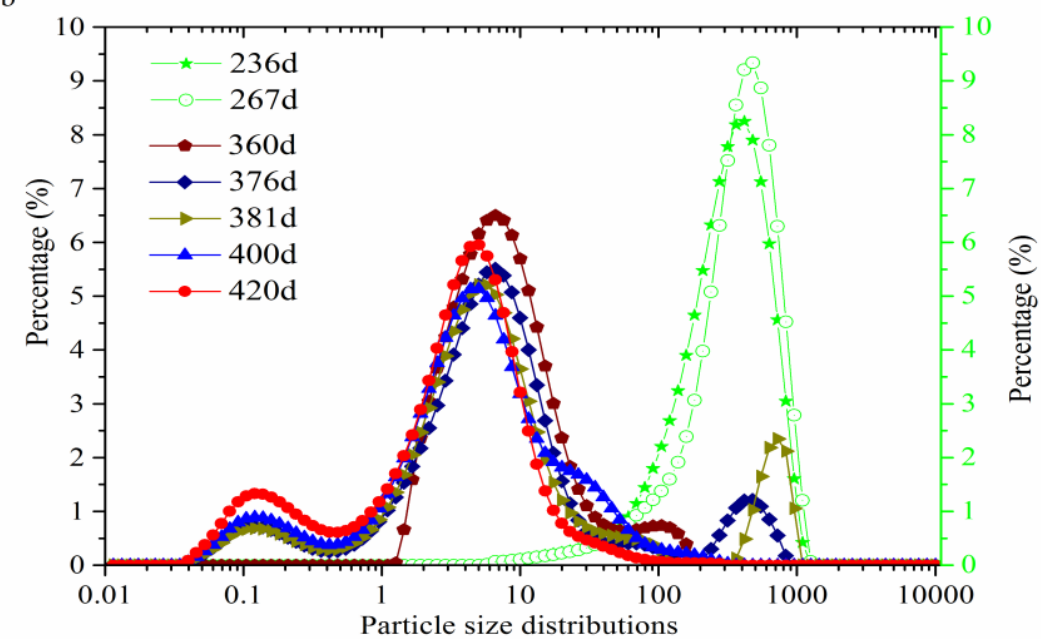

Figure 3. MLSS and MLVSS (a) and Particle size distributions during the process (b).

This decreasing of MLSS was due to cleaning strategy and SRT application during the operation, when the permeate cleaning was stopped for two to three days, it illustrated that MLSS increases (Figure 3a) on days 360, 430, 460-480, and 515. In this study, at an OLR of 0.25 , the total proteins and total carbohydrate were low compared to the second phase with an OLR of $0.7 \mathrm{~kg} / \mathrm{m}^{3} \cdot \mathrm{d}$ (Table 1). The increase of the OLR reflects the rise of the HRT, which affected the membrane performance due to the accumulation of inorganic particles and extracellular polymeric substance (EPS) in the bioreactor (Table 1). The increases of the OLR was also reported to have significant impacts on the AnMBR performance and cause the membrane fouling [38]. In the AnMBR system, decoupling of SRT from HRT provides a superior organic loading rate [39], because short HRT and high MLSS could be achieved. However, longer SRT and shorter HRT can cause higher sludge concentration and release soluble microbial products (SMPs) [40] leading to negative effects on membrane flux [41]. Considering 
that a longer HRT results in a larger footprint and a longer SRT leads to the decrease of the membrane flux, a shorter HRT and SRT (close to 50 days or more) should, therefore, be optimized for AnMBR design and operation [42].

Table 1. The major operational parameters and results in different stages of the AnMBR ${ }^{1}$.

\begin{tabular}{cccc}
\hline Parameters & Start Up & I & II \\
\hline Membrane properties & Tubular membrane, & Tubular membrane, & Tubular membrane, \\
Surface areas (m $\left.{ }^{2}\right)$ & PVDF, 0.01 & PVDF, 0.01 & 0.022 \\
\hline SRT(days) & - & 100 & 100 \\
HRT (hours) & 37.5 & 37.5 & 13.0 \\
MLSS (g/L) & - & $7.51 \pm 1.41$ & $5.00 \pm 1.09$ \\
MLVSS (g/L) & - & $5.69 \pm 0.96$ & $3.33 \pm 0.77$ \\
MLVSS/MLSS & - & $0.77 \pm 0.13$ & $0.66 \pm 0.07$ \\
Total proteins (mg/gMLVSS) & - & $66.75 \pm 22.84$ & $77.98 \pm 22.29$ \\
Total carbohydrate (mg/gMLVSS) & - & $23.24 \pm 14.10$ & $36.91 \pm 10.18$ \\
Feed sCOD (mg/L) & $456.02 \pm 44.28$ & $445.41 \pm 95.56$ & $562.80 \pm 90.56$ \\
Effluent sCOD (mg/L) & $167.89 \pm 47.92$ & $39.57 \pm 25.26$ & $31.06 \pm 5.05$ \\
Mixed liquor COD (\%) & - & $82.51 \pm 5.42$ & $87.33 \pm 3.48$ \\
sCOD Removal efficiency (\%) & $62.88 \pm 10.73$ & $91.09 \pm 4.88$ & $94.43 \pm 1.71$ \\
Feed NH N $_{4}$ (mg/L) & - & $42.80 \pm 3.23$ & $51.73 \pm 8.62$ \\
Effluent NH $_{4}$-N (mg/L) & - & $48.93 \pm 2.26$ & $55.34 \pm 7.20$ \\
\hline
\end{tabular}

${ }^{1}$ SRT, Sludge Retention Time; HRT, hydraulic retention time; MLSS, Mixed Liquor Suspended Solids; MLVSS, Mixed liquor volatile suspended solids; sCOD, Soluble chemical oxygen demand; COD, chemical oxygen demand; PVDF, polyvinylidene fluoride.

\subsection{Membrane Fouling Characteristics}

\subsubsection{Membrane Flux and Total Filtration Resistance}

Membrane performance is usually characterized using membrane flux and total filtration resistance. A tubular membrane with the original flux of $165 \mathrm{~L} / \mathrm{m}^{2} \mathrm{~h}$ was used in this study, after more than two months of treating simulated wastewater, the flux declined a flux of $25 \mathrm{~L} / \mathrm{m}^{2} \mathrm{~h}$. When the membrane flux was less than $25 \mathrm{~L} / \mathrm{m}^{2} \mathrm{~h}$, chemical cleaning was applied on days 210, 330, 500, and 570, respectively, as shown in Figure 4 . The permeate cleaning cycle of the membrane was able to remove pollutants, and raise the flux slightly, as shown in Figure 4, but it might not be effective enough at removing foulants that are held inside pores [43], and chemical cleaning is, thus, necessary to remove foulants inside the pores and restore the flux in comparison with the original flux. The chemical cleaning frequency depended on the decrease of the membrane flux and the sharp rise of total filtration resistance. The subsequent chemical cleaning with alkali and acid weakened the adhesion of the cake layer to the membrane surface, and improved the flux recovery to about $80.62 \pm 0.03 \%$, Figure S1a. This sequential cleaning of the membrane showed that alkaline cleaning was better able to remove adsorbed organic matter, Figure S1a and the acid cleaning was effective for the removal of precipitated salts and inorganic colloids, such as $\mathrm{CaCO}_{3}$ and iron oxide. This strategy of chemical cleaning showed the promising cleaning effectiveness and the flux recovery. For better understanding of the cleaning efficiency of each chemical, the application of each chemical was tested separately. 


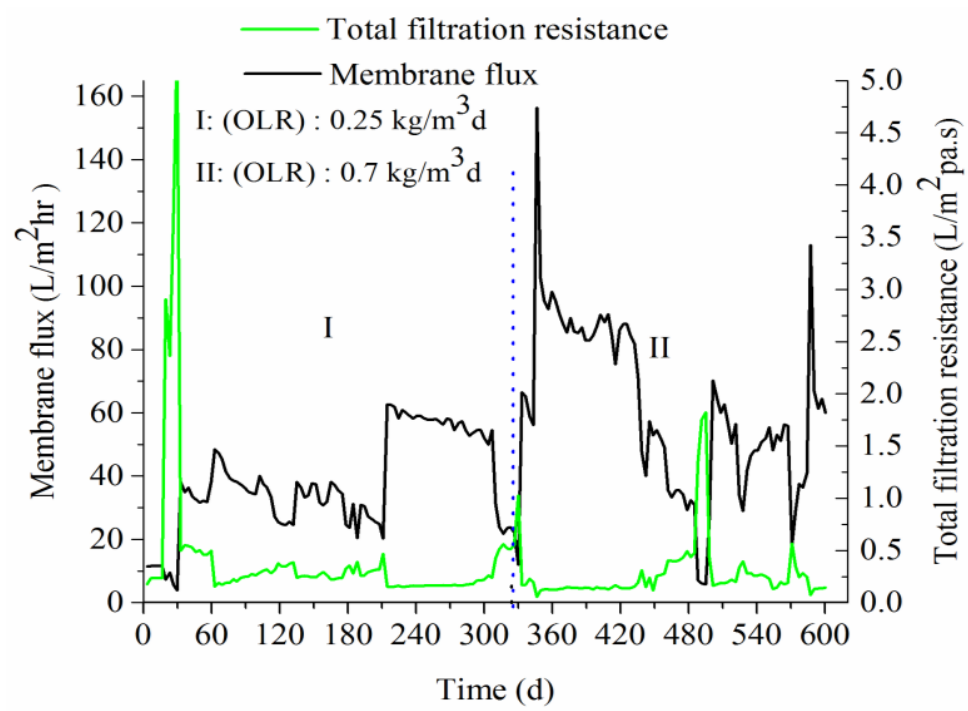

Figure 4. Membrane flux and membrane resistance fluctuations.

At this stage of cleaning, membrane cleaning with permeate water was reported to restore the flux from $30.7 \pm 0.01 \%$ of the fouled membrane to $50.24 \pm 0.02 \%$ of the cleaned membrane, but flux was not sustainable for long periods of operation. However, chemical cleaning with either alkaline or acid showed that citric acid was the least effective, with a flux recovery of $57.38 \pm 0.02 \%$, with sodium hydroxide having a flux recovery of $69.83 \pm 0.03 \%$, and sodium hypochlorite having a flux recovery of $73.90 \pm 0.03 \%$. Both sodium hydroxide and sodium hypochlorite cleanings were comparatively effective for flux recovery of the fouled membrane (Figure S1b). The membrane flux recovery [44] and fouling ratio [45] were measured as follows:

$$
\text { Flux recovery rate }(\%)=\mathrm{Jw}_{\mathrm{c}} / \mathrm{Jw}_{\mathrm{i}}
$$

where $\mathrm{Jw}_{\mathrm{c}}$ is the flux after the application of chemical cleaning solution, $\mathrm{Jw}_{\mathrm{i}}$ is the flux of the virgin membrane.

$$
\text { Membrane fouling ratio }(\%)=\mathrm{Jw}_{\mathrm{f}} / \mathrm{Jw}_{\mathrm{i}}
$$

where $\mathrm{Jw}_{\mathrm{i}}=$ flux of virgin membrane and $\mathrm{Jw}_{\mathrm{f}}=$ permeate flux after a period of running.

\subsubsection{Particle Size Distribution}

As shown in Figure 3b, the size and particle distribution of the sludge in the AnMBR changed in the course of operation time. The mean particle size was in range of 600-700 $\mu \mathrm{m}$ with a unimodal distribution curve in the first stage operated for nearly 300 days at $0.25 \mathrm{~kg} \mathrm{COD} \mathrm{m}^{-3} \mathrm{~d}^{-1}$, and changed to the mean diameter of $(7-10 \mu \mathrm{m})$ with a bimodal distribution curve in the second stage at $0.70 \mathrm{~kg}$ COD m ${ }^{-3} \mathrm{~d}^{-1}$. The extracelular polymeric substance and particle size (Figure $3 \mathrm{~b}$ ) showed the change according to the operational conditions. As a result, this triggered the decreases of membrane flux in the second stage (Figure 4).

The small particles are reported to govern the membrane fouling [13], as these fine particles deposited easily inside the membrane pores, as well as on the membrane surface [38,46]. This change in particle size was attributed to the shear force influence induced by mechanical mixing in the AnMBR and circulation of concentrate [47], in the tubular membrane, and the tubular membrane cross-flow velocity was $0.11 \mathrm{~m} / \mathrm{s}$. 


\subsection{Membrane Foulants}

\subsubsection{Fluorescence Spectroscopic Analysis}

Excitation emission matrix fluorescence spectroscopy has been commonly used to characterize the dissolved organic matter in water and soil [48]. As shown in Figure 5, In the first and second stage of experiment, there were strong tyrosine-like fluorescence and soluble microbial product-like fluorescence with peaks at the Ex/Em of 225/335 nm nominated as (Peak A) and 275/340 nm (Peak B) in the influent. The research conducted by $[48,49]$, reported the boundaries of EEM spectrum into five regions grouped into four categories: Ex and Em range in regions I and II (Ex/Em = 200-250/200-380 nm, as simple aromatic protein-like substances; Region III (Ex/Em = 200-250/380-500 nm, fulvic acid-like materials; Region IV (Ex/Em = 250-280/200-380nm, soluble microbial byproduct-like materials); and Region V (Ex/Em = 280-500/380-500 nm, humic acid-like organics).
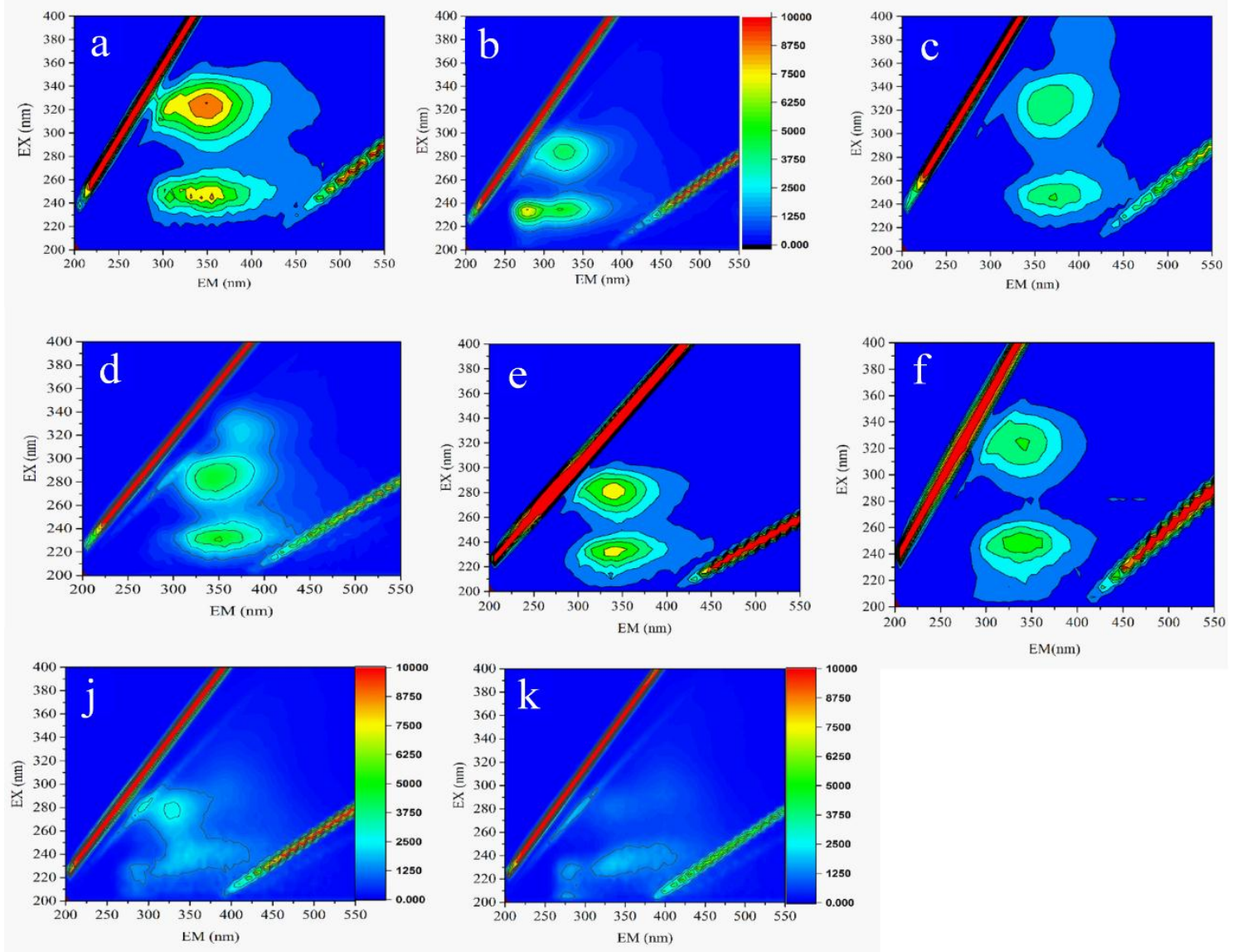

Figure 5. EEM fluorescence spectra of EPS extracted, (a) EEM-influent stage I, (b) EEM-influent stage II, (c) bEPS-AnMBR stage I, (d) bEPS-AnMBR stage II, (e) sEPS- AnMBR stage I, (f) sEPS-AnMBR stage II,

(j) EEM-effluent stage I, and (k) EEM-effluent stage II.

The influent peaks indicate two peaks in regions I and II which were suggested to be of protein-like substances associated with the aromatic amino acids and tryptophan, in agreement with the previous research [32], and the fluorescence peaks III and IV were related to the presence of fulvic and humic acid-like substances [50]. The AnMBR EEM peaks exhibited the high intensity of the peaks, two peaks, which are located around Ex/Em = 225-235/295-310 nm (Peak A) and Ex/Em = 225-235/330-350 nm (Peak B) as listed in Table 2 and Figure 5, these new peaks were identified from the EEM spectra of bound EPS, namely Ex/E = 310-330/370-400 nm (Peak D) associated with humic acid-like substances. 
Table 2. Fluorescence contour of influent, AnMBR (sEPS and bEPS) and AnMBR effluent in the first and second stage.

\begin{tabular}{cccccc}
\hline \multicolumn{2}{c}{ Peaks Locations } & Peak A & Peak B & Peak C & Peak D \\
\hline \multicolumn{2}{c}{ Influent $(\mathrm{nm})$} & $225-240 / 300-340$ & $280-320 / 320-360$ & ND & ND \\
\hline \multirow{2}{*}{ AnMBR $(\mathrm{nm})$} & Bound EPS & $235-240 / 340-355$ & $280-320 / 340-360$ & ND & $310-330 / 370-400$ \\
& Soluble EPS & $235-240 / 340-355$ & $300-350 / 320-360$ & ND & $285 / 405$ \\
\hline \multicolumn{2}{c}{ Effluent $(\mathrm{nm})$} & $235-240 / 340-355$ & $300-350 / 320-360$ & $240 / 415$ & $285 / 405$ \\
\hline
\end{tabular}

The effluent EEM peaks intensity appeared weak, especially in the second phase (Figure 5), which associated with high COD removal above $94 \%$, (Figure 2). This lesser intensity of the peaks in effluent underlined the ability of tubular membrane to retain the organic matter. The new peaks were identified from the EEM spectra of effluent, namely Ex/E = 240/415 nm (Peak C) and Ex/E = 285/405 (Peak D) associated with fulvic acid-like. This result highlighted that protein is predominant of organic matter in the AnMBR, in agreement with previous findings [51]. Gel permeation chromatography results showed that fouling after tap water cleaning exhibited many peaks which indicated more organic matter removal on the membrane wall, but this cleaning might not be enough to sustain the flux for long-term performance (Figure 4). After sequential cleaning with alkaline and acid, there were apparently three main peaks (Figure S1c) corresponding to humic and fulvic substances, humic and fulvic acids, which were located at $\pm 1000 \mathrm{Da}$ in agreement with [52,53]. Proteins and polysaccharides with a characteristic of high MW (>10,000 Da) [52,53] corresponded to the water and alkaline cleaning, which showed the ability of each cleaning reagent in sequential cleaning. The acid cleaning removed low molecular weight with the same peaks with water cleaning, but acid manifested the high intensity, as citric acid samples were diluted hundred times.

\subsubsection{FTIR Analysis}

In this study, Fourier transform infrared spectroscopy (FTIR) analysis was carried out to investigate the group functional of the AnMBR sludge, concentrate, fouling layers, and fouled and cleaned membranes, and data are shown in Figure S2a,b,c. The Figure S2a, the peak at $2500-3700 \mathrm{~cm}^{-1}$ is suggested to represent the stretching of the $\mathrm{O}-\mathrm{H}$ bond [54] and $1413 \mathrm{~cm}^{-1}$ (C-N stretch) may indicate the secondary and tertiary amines. Figure S2b spectra exhibits absorption band around $1052 \mathrm{~cm}^{-1}$, which can be assigned to the $\mathrm{C}-\mathrm{O}$ stretching of polysaccharides or polysaccharide-like substances [55] and $1157 \mathrm{~cm}^{-1}$ band suggested to be assigned to $\mathrm{C}-\mathrm{O}$ bond of ethers or carboxylic acid [53]. Figure S2b also showed three groups of bands near 1762,1652 , and $1578 \mathrm{~cm}^{-1}$ [56] in fouling layer after $\mathrm{NaOH}$, $\mathrm{NaOCl}$ and citric acid cleaning. These bands are suggested to be related to carbonyl, amide I, and amide II structure, which indicated the proteins [57]. The peaks at $1375 \mathrm{~cm}^{-1}$ (C-N stretch) and $3417 \mathrm{~cm}^{-1}(\mathrm{~N}-\mathrm{H}$ stretch) in the fouling layer are assigned to the primary and secondary amines.

The fouled and cleaned membranes showed strong and wide special band of peaks around (1000-1271) $\mathrm{cm}^{-1}$ (Figure S2c), these bands are suggested to be the aluminum silicate peaks [49], which are also confirmed with the EDS findings with high abundances of aluminum and silicon and acid manifested its powerful cleaning towards inorganic-based colloids. Figure S2c exhibited the peaks appeared in fouling layer (Figure S2b) but with low intensity in the regions around $1375 \mathrm{~cm}^{-1}$ (C-N stretch) bands corresponding to primary and secondary amines. The peaks in the ranges of 3500-3300, 1490-1440, and 850-750 $\mathrm{cm}^{-1}$ could be assigned to $\mathrm{N}-\mathrm{H}$ stretching and $\mathrm{C}-\mathrm{N}$ stretching of the amides [58]. All the peaks related to the cleaned membrane exhibited low absorbance intensities, Figure S2c, confirming reduction of foulants. Results obtained from the FTIR analysis showed the presence of proteins, carbohydrates, and inorganic elements in fouling layers, concentrate, and fouled membrane as membrane foulants in agreement with EPS findings, Figure 6, EEM (Table 2), and SEM-EDS analysis (Table 3). 


\subsubsection{SEM-EDS Analysis of the Fouling Composition}

The elemental compositions obtained from the SEM-EDS analysis of fouled and cleaned membranes indicated that the major elements of foulants were $\mathrm{C}, \mathrm{O}, \mathrm{F}, \mathrm{P}, \mathrm{Si}, \mathrm{Ca}^{2+}$, and $\mathrm{S}$, minor elements were $\mathrm{N}$ and $\mathrm{Mg}$, while the traces of $\mathrm{Na}^{+}, \mathrm{Cl}^{-}, \mathrm{K}^{+}$, and $\mathrm{Fe}^{2+}$ were also found. Precipitates containing magnesium, calcium, ammonium, and phosphate are generally spotted in anaerobic digestion [59] and have been found in AnMBR concentrate and fouled membrane layer analyses. The chemical compounds containing calcium, magnesium, phosphate, and ammonium are suggested to be formed, such as struvite formation [22] and vivianite $\left(\mathrm{Fe}_{3}\left(\mathrm{PO}_{4}\right)_{2} \cdot 8\left(\mathrm{H}_{2} \mathrm{O}\right)\right.$ [60]. The organic compounds contain ionizable groups including carboxyl group $\left(\mathrm{COO}^{-}\right)$, can precipitate $\mathrm{Ca}^{2+}, \mathrm{Mg}^{2+}, \mathrm{Al}^{3+}$, and $\mathrm{Fe}^{3+}$ found in the fouling layer. Li et al. [61] reported that the cations, such as magnesium, calcium, and sodium, present the ability to adhere to the organic foulants, such as the humic acid group functional $\left(\mathrm{COO}^{-}\right)$, in the fouling layer and the adhesion force increased in this order $\mathrm{Ca}^{2+}>\mathrm{Mg}^{2+}>\mathrm{Na}^{+}$, with calcium exhibiting much ability to bind on the $\left(\mathrm{COO}^{-}\right)$group functional of foulants in the fouling layer. Figure S3d and Table 3 revealed that most abundant elements in fouled membrane were iron of $13.20 \pm 1.11 \%$, sulfur of $12.09 \pm 4.82 \%$, phosphorus of $3.89 \pm 1.76 \%$, calcium of $3.64 \pm 0.16 \%$, silicon of $3.45 \pm 0.33 \%$, chloride of $2.66 \pm 0.00 \%$, and $\mathrm{Mg}$ of $1.69 \pm 0.47 \%$ concentrations. After membrane cleaning, a slight raising in the carbon and fluoride content are suggested to be the results of the detection of elemental membrane, because the fouling that can be the result of increasing fluoride and carbon were removed. On other hand, the carbon elements can be increased after citric acid cleaning due to adhesion of the citric acid residue on the membrane (Table 3), however, oxygen element, during the membrane fouling exhibited high relative abundance, suggested to be the organic and inorganic fouling deposited on the surface of the membrane, after cleaning the membrane, the relative abundance of the oxygen element decreased, thus, energy dispersive X-ray (EDX) can detect oxygen in membrane structure (Table 3).

Table 3. SEM-EDS composition of fouled membrane (a), alkaline cleaned membrane (b), citric acid cleaned membrane (c) (\%) in the second stage and SEM-EDS of sludge from membrane tube (d) in the first stage.

\begin{tabular}{|c|c|c|c|c|}
\hline Parameters & Fouled Membrane (a) & $\begin{array}{c}\text { Cleaned Membrane with } \\
\text { Alkaline (b) }\end{array}$ & $\begin{array}{c}\text { Cleaned Membrane with } \\
\text { Citric Acid (c) }\end{array}$ & $\begin{array}{l}\text { Sludge from the } \\
\text { Membrane Tube (d) }\end{array}$ \\
\hline $\mathrm{C}$ & $14.13 \pm 0.67$ & 37.08 & 43.65 & $34.32 \pm 1.92$ \\
\hline $\mathrm{N}$ & $2.94 \pm 2.68$ & 1.95 & 1.08 & $9.53 \pm 1.80$ \\
\hline $\mathrm{O}$ & $10.62 \pm 12.22$ & 6.00 & 3.28 & $46.52 \pm 1.19$ \\
\hline $\mathrm{F}$ & $5.51 \pm 7.79$ & 21.4 & 38.84 & - \\
\hline $\mathrm{Na}$ & $1.80 \pm 0.50$ & 12.15 & 2.95 & $0.44 \pm 0.178$ \\
\hline $\mathrm{Mg}$ & $1.69 \pm .47$ & 0.91 & 1.11 & - \\
\hline $\mathrm{Al}$ & $3.45 \pm .48$ & 0.99 & 1.02 & $1.40 \pm 0.36$ \\
\hline $\mathrm{Si}$ & $3.45 \pm .33$ & 1.09 & 1.3 & $3.25 \pm 1.23$ \\
\hline $\mathrm{P}$ & $3.89 \pm 1.76$ & 1.26 & 1.14 & $1.57 \pm 1.50$ \\
\hline $\mathrm{S}$ & $12.09 \pm 4.82$ & 1.25 & 1.05 & $0.57 \pm 0.12$ \\
\hline $\mathrm{Cl}$ & $2.66 \pm 0.00$ & 4.85 & 1.15 & - \\
\hline $\mathrm{K}$ & $1.52 \pm 0.47$ & 0.74 & 0.83 & $0.08 \pm 0.02$ \\
\hline $\mathrm{Ca}$ & $3.64 \pm 0.16$ & 0.97 & 0.73 & $0.11 \pm 0.06$ \\
\hline $\mathrm{Fe}$ & $13.20 \pm 1.11$ & 7.48 & 0.00 & $1.93 \pm 0.57$ \\
\hline $\mathrm{Cu}$ & $7.52 \pm 6.05$ & 1.85 & 1.87 & $0.16 \pm 0.04$ \\
\hline
\end{tabular}

After cleaning with citric acid, iron and calcium scalants spotted on the membrane surface were $0.00 \%$ and $0.73 \%$, respectively (Table 3 ). However, the alkaline cleaning showed the remaining of $7.48 \%$ iron and $0.97 \%$ calcium on surface of the membrane. The citric acid exhibited a powerful cleaning efficiency toward these inorganic-based colloids (Table 3) compared to the alkaline solution; these results were supported with other research findings [62].The high amount of chloride and sodium found after alkaline solutions cleaning were residues of alkaline cleaning solutions. At $0.25 \mathrm{~kg} \mathrm{COD} \mathrm{m}^{-3} \mathrm{~d}^{-1}$ of ORL, the SEM-EDS analysis of concentrate showed low composition of inorganic elements (Table 3 ) and inorganic fouling exhibited marginal contribution to the membrane 


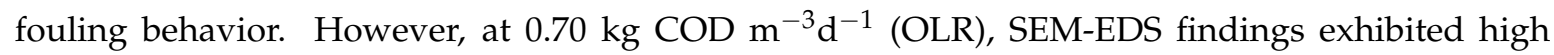
concentrations of inorganic fouling, which supported essential contribution of inorganic foulants on membrane fouling behavior (Table 3). Figure 6 indicates the composition of the AnMBR EPS during the long process of the operation and its content played a vital role in membrane fouling. The proteins dominated in both soluble microbial products and bound EPS (Table 1). The EPS constituents has been reported as the main cause of membrane fouling [34], Luna et al. [32] reported that the proteins have a hydrophobic tendency, while carbohydrates manifest a hydrophilic tendency.

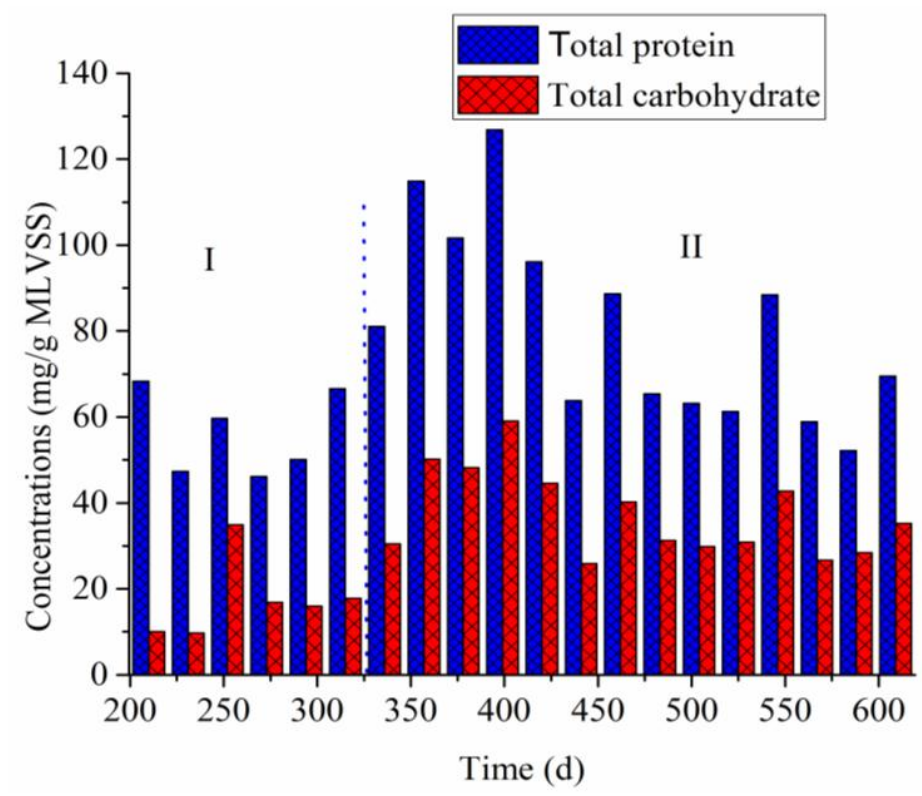

Figure 6. Soluble microbial products and bound EPS of the AnMBR during the process.

\section{Conclusions}

The side-stream AnMBR equipped with a tubular membrane exhibited the COD removal of $91.09 \pm 4.88 \%$ at $0.25 \mathrm{~kg} \mathrm{COD} \mathrm{m}^{-3} \mathrm{~d}^{-1}$, and $94.43 \pm 1.71 \%$ at $0.70 \mathrm{~kg} \mathrm{COD} \mathrm{m}^{-3} \mathrm{~d}^{-1}$, respectively. A cleaning strategy of periodical permeate membrane cleaning, through the recirculation, removed a variety of high and low molecular weight foulants on the membrane surface, but was not effective at removing foulants that are held inside pores, therefore, a cleaning strategy with permeating recirculation and sequential chemical cleaning of alkaline and acid solutions were most effective to recover the membrane flux. The alkaline solution removed a variety of foulants with much emphasis on organic fouling, however, the citric acid solution proved to remove a wide range of scalants. At the first phase of operation with low organic loading rate of $0.25 \mathrm{~kg} \mathrm{COD} \mathrm{m}^{-3} \mathrm{~d}^{-1}$, the AnMBR membrane was mainly affected with organic fouling, the excitation emission matrices and extracellular polymeric substance findings illustrated that proteins and carbohydrates, humic acid, and fulvic acid were prone to be trapped in the cake layers and responsible for pore blockage. However, the increasing of the OLR to $0.70 \mathrm{~kg} \mathrm{COD} \mathrm{m}^{-3} \mathrm{~d}^{-1}$, implied concurrently increases of the high proteins and inorganic particles in the bioreactor, which triggered the membrane fouling behavior, thus, the essential contribution of both proteins and inorganic foulants on membrane fouling were significant.

Supplementary Materials: The following are available online at http:/ / www.mdpi.com/2227-9717/6/5/50/s1, Figure S1: Subsequent chemical cleaning and flux recovery (a); chemical cleaning comparison with different cleaning reagent abilities (b); and HPSEC responses of organic matters in foulants (c). Figure S2: FT-IR spectra of (a): AnMBR sludge, (b): sludge from cleaned membrane with $(\mathrm{NaOH}$ and $\mathrm{NaClO}), \mathrm{NaOH}$, and citric acid, (c): fouled membrane layer and cleaned membrane with $(\mathrm{NaOH}$ and $\mathrm{NaClO}), \mathrm{NaOH}$, and citric acid. Figure S3: SEM of the fouled membrane $\left(a, a^{\prime}\right)$, alkaline cleaned membrane $\left(b, b^{\prime}\right)$, and citric acid cleaned membrane $\left(c, c^{\prime}\right)$; and SEM-EDS of the fouled membrane (d), alkaline cleaned membrane (e), and citric acid cleaned membrane (f) 
Author Contributions: N.M.V. designed the experiments, performed the experiments, analyzed the data, and wrote the paper. J.T. designed part of the experiments, and analyzed the data. D.Y. designed part of the experiments and analyzed the data, J.Z. designed part of the experiments and analyzed data, Y.S.W. conceived and designed part of the experiments, analyzed the data, and wrote the paper.

Acknowledgments: The authors gratefully acknowledge the financial support from the National Key Research and Development Program of China (2016YFE0118500), Major Science and Technology Program for Water Pollution Control and Treatment of China (2015ZX07203-005), National Natural Science Foundation of China (21677161), Key Research and Development Program of Jiangxi Province, China (20171ACG70018), and CAS-TWAS President's Fellowship Programme for Doctoral Candidates.

Conflicts of Interest: The authors declare no conflict of interest.

\section{References}

1. Ichinari, T.; Ohtsubo, A.; Ozawa, T.; Hasegawa, K.; Teduka, K.; Oguchi, T.; Kiso, Y. Wastewater treatment performance and sludge reduction properties of a household wastewater treatment system combined with an aerobic sludge digestion unit. Process Biochem. 2008, 43, 722-728. [CrossRef]

2. Hawkins, D.E.; Khan, M.M. 11 Ecotourism opportunities for developing countries. In Global Tourism; Taylor \& Francis: Abingdon, UK, 1998; p. 191.

3. Bolzonella, D.; Fatone, F.; di Fabio, S.; Cecchi, F. Application of membrane bioreactor technology for wastewater treatment and reuse in the Mediterranean region: Focusing on removal efficiency of non-conventional pollutants. J. Environ. Manag. 2010, 91, 2424-2431. [CrossRef] [PubMed]

4. Orhon, D.; Sözen, S.; Görgün, E.; Çokgör, E.U.; Artan, N. Technological aspects of wastewater management in coastal tourist areas. Water Sci. Technol. 1999, 39, 177-184.

5. Yang, B.; Wang, M.; Wang, J.; Song, X.; Wang, Y.; Xu, H.; Bai, J. Mechanism of high contaminant removal performance in the expanded granular sludge blanket (EGSB) reactor involved with granular activated carbon for low-strength wastewater treatment. Chem. Eng. J. 2018, 334, 1176-1185. [CrossRef]

6. Ratanatamskul, C.; Siritiewsri, T. A compact on-site UASB-EGSB system for organic and suspended solid digestion and biogas recovery from department store wastewater. Int. Biodeterior. Biodegrad. 2015, 102, $24-30$. [CrossRef]

7. Martinez-Sosa, D.; Helmreich, B.; Netter, T.; Paris, S.; Bischof, F.; Horn, H. Anaerobic submerged membrane bioreactor (AnSMBR) for municipal wastewater treatment under mesophilic and psychrophilic temperature conditions. Bioresour. Technol. 2011, 102, 10377-10385. [CrossRef] [PubMed]

8. Lettinga, G.; Rebac, S.; Zeeman, G. Challenge of psychrophilic anaerobic wastewater treatment. Trends Biotechnol. 2001, 19, 363-370. [CrossRef]

9. Amani, T.; Nosrati, M.; Sreekrishnan, T. Anaerobic digestion from the viewpoint of microbiological, chemical, and operational aspects-A review. Environ. Rev. 2010, 18, 255-278. [CrossRef]

10. Aiyuk, S.; Forrez, I.; van Haandel, A.; Verstraete, W. Anaerobic and complementary treatment of domestic sewage in regions with hot climates-A review. Bioresour. Technol. 2006, 97, 2225-2241. [CrossRef] [PubMed]

11. Smith, A.L.; Stadler, L.B.; Love, N.G.; Skerlos, S.J.; Raskin, L. Perspectives on anaerobic membrane bioreactor treatment of domestic wastewater: A critical review. Bioresour. Technol. 2012, 122, 149-159. [CrossRef] [PubMed]

12. Krzeminski, P.; Leverette, L.; Malamis, S.; Katsou, E. Membrane bioreactors-a review on recent developments in energy reduction, fouling control, novel configurations, LCA and market prospects. J. Membr. Sci. 2017. [CrossRef]

13. Ozgun, H.; Dereli, R.K.; Ersahin, M.E.; Kinaci, C.; Spanjers, H.; van Lier, J.B. A review of anaerobic membrane bioreactors for municipal wastewater treatment: Integration options, limitations and expectations. Sep. Purif. Technol. 2013, 118, 89-104. [CrossRef]

14. Judd, S. The MBR book: Principles and Applications of Membrane Bioreactors for Water and Wastewater Treatment; Elsevier: New York, NY, USA, 2010.

15. Gao, W.; Liang, H.; Ma, J.; Han, M.; Chen, Z.; Han, Z.; Li, G. Membrane fouling control in ultrafiltration technology for drinking water production: A review. Desalination 2011, 272, 1-8. [CrossRef]

16. Feng, R.; Wang, C.; Xu, X.; Yang, F.; Xu, G.; Jiang, T. Highly effective antifouling performance of $\mathrm{N}$-vinyl-2-pyrrolidone modified polypropylene non-woven fabric membranes by ATRP method. J. Membr. Sci. 2011, 369, 233-242. [CrossRef] 
17. Meng, F.; Chae, S.-R.; Drews, A.; Kraume, M.; Shin, H.-S.; Yang, F. Recent advances in membrane bioreactors (MBRs): Membrane fouling and membrane material. Water Res. 2009, 43, 1489-1512. [CrossRef] [PubMed]

18. Lin, H.; Peng, W.; Zhang, M.; Chen, J.; Hong, H.; Zhang, Y. A review on anaerobic membrane bioreactors: Applications, membrane fouling and future perspectives. Desalination 2013, 314, 169-188. [CrossRef]

19. Le-Clech, P.; Chen, V.; Fane, T.A. Fouling in membrane bioreactors used in wastewater treatment. J. Membr. Sci. 2006, 284, 17-53. [CrossRef]

20. Jarusutthirak, C.; Mattaraj, S.; Jiraratananon, R. Influence of inorganic scalants and natural organic matter on nanofiltration membrane fouling. J. Membr. Sci. 2007, 287, 138-145. [CrossRef]

21. Chen, J.P.; Kim, S.; Ting, Y. Optimization of membrane physical and chemical cleaning by a statistically designed approach. J. Membr. Sci. 2003, 219, 27-45. [CrossRef]

22. Wang, Z.; Ma, J.; Tang, C.Y.; Kimura, K.; Wang, Q.; Han, X. Membrane cleaning in membrane bioreactors: A review. J. Membr. Sci. 2014, 468, 276-307. [CrossRef]

23. Belfort, G.; Davis, R.H.; Zydney, A.L. The behavior of suspensions and macromolecular solutions in crossflow microfiltration. J. Membr. Sci. 1994, 96, 1-58. [CrossRef]

24. Popović, S.; Milanović, S.; Iličić, M.; Djurić, M.; Tekić, M. Flux recovery of tubular ceramic membranes fouled with whey proteins. Desalination 2009, 249, 293-300. [CrossRef]

25. Tin, M.M.M.; Anioke, G.; Nakagoe, O.; Tanabe, S.; Kodamatani, H.; Nghiem, L.D.; Fujioka, T. Membrane fouling, chemical cleaning and separation performance assessment of a chlorine-resistant nanofiltration membrane for water recycling applications. Sep. Purif. Technol. 2017, 189, 170-175. [CrossRef]

26. Mei, X.; Quek, P.J.; Wang, Z.; Ng, H.Y. Alkali-assisted membrane cleaning for fouling control of anaerobic ceramic membrane bioreactor. Bioresour. Technol. 2017. [CrossRef] [PubMed]

27. Zondervan, E.; Roffel, B. Evaluation of different cleaning agents used for cleaning ultra filtration membranes fouled by surface water. J. Membr. Sci. 2007, 304, 40-49. [CrossRef]

28. American Public Health Association; American Water Works Association; Water Pollution Control Federation; Water Environment Federation. Standard Methods for the Examination of Water and Wastewater, 21st ed.; American Public Health Association/American Water Works Association/Water Environment Federation: Washington, DC, USA, 2005.

29. Dubois, M.; Gilles, K.A.; Hamilton, J.K.; Rebers, P.; Smith, F. Colorimetric method for determination of sugars and related substances. Anal. Chem. 1956, 28, 350-356. [CrossRef]

30. Xiao, P.; Xiao, F.; Wang, D.; Qin, T.; He, S. Investigation of organic foulants behavior on hollow-fiber UF membranes in a drinking water treatment plant. Sep. Purif. Technol. 2012, 95, 109-117. [CrossRef]

31. Ji, Q.; Liu, H.; Hu, C.; Qu, J.; Wang, D.; Li, J. Removal of disinfection by-products precursors by polyaluminum chloride coagulation coupled with chlorination. Sep. Purif. Technol. 2008, 62, 464-469. [CrossRef]

32. Luna, H.; Baeta, B.E.L.; Aquino, S.F.; Susa, M.R. EPS and SMP dynamics at different heights of a submerged anaerobic membrane bioreactor (SAMBR). Process Biochem. 2014, 49, 2241-2248. [CrossRef]

33. Ho, J.; Sung, S. Methanogenic activities in anaerobic membrane bioreactors (AnMBR) treating synthetic municipal wastewater. Bioresour. Technol. 2010, 101, 2191-2196. [CrossRef] [PubMed]

34. Chu, L.-B.; Yang, F.-L.; Zhang, X.-W. Anaerobic treatment of domestic wastewater in a membrane-coupled expended granular sludge bed (EGSB) reactor under moderate to low temperature. Process Biochem. 2005, 40, 1063-1070. [CrossRef]

35. Gao, W.; Leung, K.; Qin, W.; Liao, B. Effects of temperature and temperature shock on the performance and microbial community structure of a submerged anaerobic membrane bioreactor. Bioresour. Technol. 2011, 102, 8733-8740. [CrossRef] [PubMed]

36. Lin, H.; Chen, J.; Wang, F.; Ding, L.; Hong, H. Feasibility evaluation of submerged anaerobic membrane bioreactor for municipal secondary wastewater treatment. Desalination 2011, 280, 120-126. [CrossRef]

37. Yue, X.; Koh, Y.K.K.; Ng, H.Y. Effects of dissolved organic matters (DOMs) on membrane fouling in anaerobic ceramic membrane bioreactors (AnCMBRs) treating domestic wastewater. Water Res. 2015, 86, 96-107. [CrossRef] [PubMed]

38. Liu, Y.; Liu, H.; Cui, L.; Zhang, K. The ratio of food-to-microorganism (F/M) on membrane fouling of anaerobic membrane bioreactors treating low-strength wastewater. Desalination 2012, 297, 97-103. [CrossRef]

39. Mahmoud, I.; Liao, B. Effects of sludge concentration and biogas sparging rate on critical flux in a submerged anaerobic membrane bioreactor. J. Water Process Eng. 2017, 20, 51-60. [CrossRef] 
40. Dereli, R.K.; Ersahin, M.E.; Ozgun, H.; Ozturk, I.; Jeison, D.; van der Zee, F.; van Lier, J.B. Potentials of anaerobic membrane bioreactors to overcome treatment limitations induced by industrial wastewaters. Bioresour. Technol. 2012, 122, 160-170. [CrossRef] [PubMed]

41. Huang, Z.; Ong, S.L.; Ng, H.Y. Submerged anaerobic membrane bioreactor for low-strength wastewater treatment: Effect of HRT and SRT on treatment performance and membrane fouling. Water Res. 2011, 45, 705-713. [CrossRef] [PubMed]

42. Mei, X.; Wang, Z.; Miao, Y.; Wu, Z. Recover energy from domestic wastewater using anaerobic membrane bioreactor: Operating parameters optimization and energy balance analysis. Energy 2016, 98, 146-154. [CrossRef]

43. Le Clech, P.; Jefferson, B.; Chang, I.S.; Judd, S.J. Critical flux determination by the flux-step method in a submerged membrane bioreactor. J. Membr. Sci. 2003, 227, 81-93. [CrossRef]

44. You, M.; Wang, P.; Xu, M.; Yuan, T.; Meng, J. Fouling resistance and cleaning efficiency of stimuli-responsive reverse osmosis (RO) membranes. Polymer 2016, 103, 457-467. [CrossRef]

45. Liikanen, R.; Yli-Kuivila, J.; Laukkanen, R. Efficiency of various chemical cleanings for nanofiltration membrane fouled by conventionally-treated surface water. J. Membr. Sci. 2002, 195, 265-276. [CrossRef]

46. Yang, M.; Yu, D.; Liu, M.; Zheng, L.; Zheng, X.; Wei, Y.; Wang, F.; Fan, Y. Optimization of MBR hydrodynamics for cake layer fouling control through CFD simulation and RSM design. Bioresour. Technol. 2017, 227, 102-111. [CrossRef] [PubMed]

47. Bai, R.; Leow, H. Microfiltration of activated sludge wastewater-The effect of system operation parameters. Sep. Purif. Technol. 2002, 29, 189-198. [CrossRef]

48. Chen, W.; Westerhoff, P.; Leenheer, J.A.; Booksh, K. Fluorescence excitation-emission matrix regional integration to quantify spectra for dissolved organic matter. Environ. Sci. Technol. 2003, 37, 5701-5710. [CrossRef] [PubMed]

49. Yamamura, H.; Okimoto, K.; Kimura, K.; Watanabe, Y. Hydrophilic fraction of natural organic matter causing irreversible fouling of microfiltration and ultrafiltration membranes. Water Res. 2014, 54, 123-136. [CrossRef] [PubMed]

50. Wu, F.; Tanoue, E. Isolation and partial characterization of dissolved copper-complexing ligands in streamwaters. Environ. Sci. Technol. 2001, 35, 3646-3652. [CrossRef] [PubMed]

51. Tang, S.; Wang, Z.; Wu, Z.; Zhou, Q. Role of dissolved organic matters (DOM) in membrane fouling of membrane bioreactors for municipal wastewater treatment. J. Hazard. Mater. 2010, 178, 377-384. [CrossRef] [PubMed]

52. Lee, N.; Amy, G.; Croué, J.-P.; Buisson, H. Identification and understanding of fouling in low-pressure membrane (MF/UF) filtration by natural organic matter (NOM). Water Res. 2004, 38, 4511-4523. [CrossRef] [PubMed]

53. Wang, J.; Li, K.; Wei, Y.; Cheng, Y.; Wei, D.; Li, M. Performance and fate of organics in a pilot MBR-NF for treating antibiotic production wastewater with recycling NF concentrate. Chemosphere 2015, 121, 92-100. [CrossRef] [PubMed]

54. Cuetos, M.J.; Gómez, X.; Otero, M.; Morán, A. Anaerobic digestion of solid slaughterhouse waste: Study of biological stabilization by Fourier Transform infrared spectroscopy and thermogravimetry combined with mass spectrometry. Biodegradation 2010, 21, 543-556. [CrossRef] [PubMed]

55. Tu, X.; Song, Y.; Yu, H.; Zeng, P.; Liu, R. Fractionation and characterization of dissolved extracellular and intracellular products derived from floccular sludge and aerobic granules. Bioresour. Technol. 2012, 123, 55-61. [CrossRef] [PubMed]

56. De Oliveira Silva, J.; Rodrigues Filho, G.; da Silva Meireles, C.; Ribeiro, S.D.; Vieira, J.G.; da Silva, C.V.; Cerqueira, D.A. Thermal analysis and FTIR studies of sewage sludge produced in treatment plants. The case of sludge in the city of Uberlândia-MG, Brazil. Thermochim. Acta 2012, 528, 72-75. [CrossRef]

57. Her, N.; Amy, G.; Park, H.-R.; Song, M. Characterizing algogenic organic matter (AOM) and evaluating associated NF membrane fouling. Water Res. 2004, 38, 1427-1438. [CrossRef] [PubMed]

58. Li, K.; Wang, J.; Liu, J.; Wei, Y.; Chen, M. Advanced treatment of municipal wastewater by nanofiltration: Operational optimization and membrane fouling analysis. J. Environ. Sci. 2016, 43, 106-117. [CrossRef] [PubMed] 
59. Zhang, J.; Padmasiri, S.; Fitch, M.; Norddahl, B.; Raskin, L.; Morgenroth, E. Influence of cleaning frequency and membrane history on fouling in an anaerobic membrane bioreactor. Desalination 2007, 207, 153-166. [CrossRef]

60. Wilfert, P.; Mandalidis, A.; Dugulan, A.; Goubitz, K.; Korving, L.; Temmink, H.; Witkamp, G.; Van Loosdrecht, M. Vivianite as an important iron phosphate precipitate in sewage treatment plants. Water Res. 2016, 104, 449-460. [CrossRef] [PubMed]

61. Li, Q.; Elimelech, M. Organic fouling and chemical cleaning of nanofiltration membranes: Measurements and mechanisms. Environ. Sci. Technol. 2004, 38, 4683-4693. [CrossRef] [PubMed]

62. Strugholtz, S.; Sundaramoorthy, K.; Panglisch, S.; Lerch, A.; Brügger, A.; Gimbel, R. Evaluation of the performance of different chemicals for cleaning capillary membranes. Desalination 2005, 179, 191-202. [CrossRef]

(C) 2018 by the authors. Licensee MDPI, Basel, Switzerland. This article is an open access article distributed under the terms and conditions of the Creative Commons Attribution (CC BY) license (http://creativecommons.org/licenses/by/4.0/). 